\title{
Chondrogenic Differentiation of Human Mesenchymal Stem Cells on a Patterned Polymer Surface
}

\author{
June Seok Heo
}

Severance Hospital, Cell Therapy Center, Seoul 03722, Korea

\section{패턴된 폴리머를 이용한 중간엽줄기세포의 연골 분화}

\author{
허준석 \\ 세브란스병원 세포치료센터
}

\begin{abstract}
Mesenchymal stem cells (MSCs) are an attractive tool in tissue engineering as they have the required potential to treat injured articular cartilage. UV-exposed DTOPV (S-triazine bridged $p$-phenylene vinylene) is a biocompatible and fluorescent polymer with a hydrophilic surface. Previous studies have demonstrated that the surface wettability and hydrophilicity play critical roles in regulating cell adhesion and proliferation. The objective of this study was to improve the potential of in vitro MSC differentiation into Chondrocytes using DTOPV. MSCs were cultured on two different substrates: (1) tissue culture polystyrene (TCPS) as a reference and (2) UV-exposed and patterned DTOPV films. Chondrogenesis of MSCs was induced for two weeks on TCPS and DTOPV in the presence of an induction medium containing transforming growth factor (TGF)- $\beta 3$. Interestingly, the MSCs on TCPS adhered and spread, while those on DTOPV tended to form aggregates within several days. The cells cultured on DTOPV for two weeks had a round morphology, with stronger Safranine O staining of the extracellular matrix than that of the cells cultured on TCPS. Also, Type // collagen gene was significantly expressed in cells induced on DTOPV. These results indicate that chondrogenic differentiation of MSCs proceeds more rapidly on DTOPV than on TCPS. Therefore, in cartilage tissue engineering, DTOPV could be used to induce effective chondrogenic differentiation of MSCs.
\end{abstract}

Keywords: Chondrogenesis, DTOPV, Mesenchymal stem cell, Tissue engineering

This is an Open Access article distributed under the terms of the Creative Commons Attribution Non-Commercial License (http://creativecommons.org/licenses/by-nc/4.0) which permits unrestricted non-commercial use, distribution, and reproduction in any medium, provided the original work is properly cited.

Copyright (@ 2015 The Korean Society for Clinical Laboratory Science. All rights reserved.
Corresponding author: June Seok Heo

Cell Therapy Center, Severance Hospital, Seoul 03722, Korea

Tel: 82-2-2228-7822

E-mail: juneseok@yuhs.ac

Received: June 1, 2015

Revised 1 1 st: June 23, 2015

Revised: $2^{\text {nd }}:$ June 25,2015

Accepted: July 2, 2015

\section{Introduction}

Mesenchymal stem cells (MSCs) were first identified by Friedenstein and Petrakova (Friedenstein AJ et al., 1966). They were initially considered as fibroblastic stem cells due to their similarity to fibroblasts in terms of morphology and colony-forming capacity. There are many similarities between MSCs and fibroblasts, however, now cells with stemness and the ability to differentiate into several cell lineages in addition to their colony-forming properties are called MSCs (Caplan Al, 1994; Jiang Y et al., 2002).

Self-renewing MSCs with multilineage potentials are maintained in an undifferentiated state under general culture conditions. However, when subjected to certain environments, MSCs can be induced to differentiate into osteocytes, adipocytes, and chondrocytes (Cho H-K, 2008). Due to this plasticity, MSCs have tremendous therapeutic potentials in regenerative medicine. However, the apparent limitations of 
using MSCs, such as low in vitro differentiation efficiency, are barriers for clinical applications. In part, these limitations may be due to the employed culture methods.

The differentiation of stem cells is greatly regulated by the cells' surrounding environment. Surface patterning of biomaterials has recently become a key technology in gene and drug delivery as well as tissue engineering (Stevens MM \& George $\mathrm{JH}, 2005)$. Furthermore, controlled patterning of biomaterials enables cell attachment, proliferation, differentiation, and protein secretion to be tuned (Shin H et al., 2003; Wang W et al., 2009). The latest studies have reported that patterning could be used to control stem cell properties such as adhesion, growth, and differentiation (You J, 2014a, 2014b).

In previous studies, it was found that UV-exposed diphenylamino-s-triazine bridged $p$-phenylene vinylene (DTOPVUV), which has a hydrophilic surface containing a carboxyl $(-\mathrm{COOH})$ group, is a good substrate that promotes efficient attachment and isolation of MSCs (You J et al., 2009; Kim H-S et al., 2010). This finding prompted to investigate the effect of this substrate on the chondrogenesis of MSCs.

In this study, a culture method using the biocompatible polymer DTOPV was used to enhance differentiation efficiency. The aim of the study was to increase the differentiation efficiency of MSCs into chondrocytes using a patterned polymer (DTOPV) and to draw a comparison with the efficiency of tissue culture polystyrene (common culture dish). In turn, we aimed to develop a new protocol for the chondrogenesis of MSCs.

\section{Materials and Methods}

\section{Reagents}

Dulbecco's modified eagle's medium (DMEM) with low glucose, fetal bovine serum (FBS), penicillin/streptomycin (P/S), phosphate buffered saline (PBS), trypsin/EDTA, and trypan blue were purchased from Invitrogen (Carlsbad, CA, USA). Safranine O was purchased from Junsei Chemical Co., Ltd (Japan). 7-amino-actinomycine D (7-AAD), CD14, CD29, CD31, CD34, CD44, CD45, CD73, CD90, CD105, and CD106 antibodies were obtained from Beckman Coulter (USA). Transforming growth factor (TGF) $-\beta 3$ and chondrogenic differentiation medium were purchased from Lonza (Walkersville, MD, USA). Tissue culture polystyrene (TCPS) was purchased from Corning (Corning Inc., NY, USA).

\section{Fabrication of DTOPV and patterned substrates}

DTOPV films were prepared by spin-coating with a solution of DTOPV in chloroform (1 wt \%) as described previously (You J et al., 2009). For pattern formation, the DTOPV films were illuminated with a high-intensity UV lamp (13.05 $\mathrm{mW} / \mathrm{cm}^{2}$ ) through a photomask. The wettability of the DTOPV surface was examined by measuring the contact angle of a deionized water drop. The DTOPV substrates and TCPS were used for the proliferation and patterning of MSC.

\section{Cell culture}

Bone marrow mononuclear cells were isolated using Ficoll-Paque (GE Healthcare, Uppsala, Sweden) after informed consent was obtained from healthy adult volunteers (approval No. 4-2014-0650), seeded at $1 \times 10^{6}$ cells per T75 flask (Nunc, Denmark) in DMEM supplemented with 10\% FBS and $1 \% \mathrm{P} / \mathrm{S}$, and incubated at $37^{\circ} \mathrm{C}$ in an incubator with $5 \%$ humidified $\mathrm{CO}_{2}$. After overnight culture, non-adherent cells were removed and adherent cells were cultured. The medium was replaced with fresh medium every three or four days. The cells were subcultured using trypsin/EDTA for further expansion when they reached $90 \%$ confluence. MSCs under passage 5 were used for this study.

\section{Immunophenotyping}

For fluorescence-activated cell sorting (FACS) analysis, MSCs were harvested and stained with the following antibodies: anti-CD14, anti-CD29, anti-CD31, anti-CD34, anti-CD44, anti-CD45, anti-CD73, anti-CD90, anti-CD105, and anti-CD106. Isotype control antibodies conjugated with fluorescein isothiocyanate (FITC) and phycoerythrin (PE) were used as negative controls. After staining, the cells were examined using a Cytomics Flow Cytometer (Beckman Coulter) and the results were analyzed using WinMDI software.

\section{Viability test}

To investigate the cytotoxicity of the substrates, MSCs 
cultivated on TCPS or DTOPV were detached and stained with 7-AAD dye. Cell viability was quantified by flow cytometry.

\section{Chondrogenic differentiation}

To induce chondrogenesis, MSCs were cultured with chondrogenic medium containing $10 \mathrm{ng} / \mathrm{mL}$ TGF- $\beta 3$. Cultures were maintained for two weeks with a change of fresh medium every three days. DMEM was used as an internal control. Chondrogenesis was analyzed by staining with Safranine O. Images were obtained using an Olympus IX71 microscope (Olympus, Tokyo, Japan).

\section{RT-PCR}

Total RNA was extracted using Trizol reagent (Invitrogen). Standard reverse transcription (RT) was performed using Transcriptase II (Invitrogen). PCR was carried out using the following conditions: $94^{\circ} \mathrm{C}$ for 4 min, followed by 35 cycles at $94^{\circ} \mathrm{C}$ for $25 \mathrm{~s}, 62^{\circ} \mathrm{C}$ for $30 \mathrm{~s}$, and $72^{\circ} \mathrm{C}$ for $45 \mathrm{~s}$, and final extension at $72^{\circ} \mathrm{C}$ for $10 \mathrm{~min}$. Glyceraldehyde-3-phosphate dehydrogenase (GAPDH) was used as an internal control. The specific primer was as follows: Type II collagen, 5'-ACGGCGAGAAGGGAGAAGTTG-3' (forward) and 5'- GGGGGTCCAGGGTTGCCATTG-3' (reverse).

\section{Results}

\section{Surface chemistry of substrates}

The substrate used for this study was a biocompatible DTOPV polymer fabricated using the Wittig polycondensation method as previously reported (Cho H \& Kim E, 2002; Yoo J et al., 2007). The vinylene group in the DTOPV structure was changed to a carboxyl group via photo-oxidation during UV exposure (Fig. 1). The formation of carboxyl groups resulted in the hydrophilic characteristic of DTOPV.

\section{Morphology and characterization of MSCs from bone marrow}

MSCs were collected and cultured from human bone marrow. When cells reached a density of $80 \%$, their photos were taken using an inverted phase microscope (Olympus IX71). Cultured MSCs displayed a spindle-shaped morphology
(Fig. 2A).

For immunophenotyping, MSCs were characterized, for the expression of specific surface markers, using flow cytometry. MSCs were negative for CD14, CD31, CD34, CD 45, and CD106, which are known markers of hematopoietic and endothelial cells. Meanwhile, they were positive for CD29, CD44, CD73, CD90, and CD105, which are known markers of MSCs (Fig. 2B). These results confirmed that the cultivated cells were MSCs.

\section{Cell growth on substrates}

To observe the growth rates of MSCs, cells were cultivated on (i) tissue culture polystyrene (TCPS), (ii) UV-exposed DTOPV, and (iii) unexposed DTOPV. The proliferation rate of MSCs cultured on UV-exposed DTOPV was very high compared with that on TCPS. During cell culture, MSCs did not exhibit further growth on unexposed DTOPV because of unstable attachment to the substrate (Fig. 3A). These results indicated that MSC growth was much more favorable on the UV-exposed DTOPV than on TCPS. Additionally, cell viability was analyzed by 7-AAD staining to examine the biocompatibility of the substrates. MSCs cultured on the three substrates displayed $>90 \%$ viability (Fig. 3B). The viability test also indicated the high biocompatibility of the DTOPV film as a MSC culture substrate.

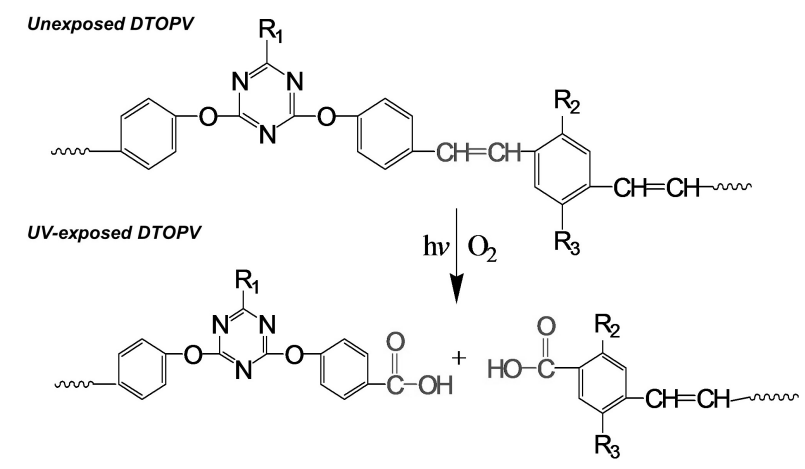

Fig. 1. Structure. Photo-oxidation of diphenylamino-s-triazine bridged $p$-phenylene vinylene polymer (DTOPV). UV-exposed area containing carboxyl groups is hydrophilic and negatively charged. DTOPV: $\mathrm{R}_{1}=$ diphenylamino, $\mathrm{R}_{2}=\mathrm{OCH}_{3}, \mathrm{R}_{3}=\mathrm{O}-\left(\mathrm{CH}_{2}\right)_{2} \mathrm{CH}\left(\mathrm{CH}_{3}\right)-\left(\mathrm{CH}_{2}\right)_{3}-\mathrm{CH}\left(\mathrm{CH}_{3}\right)_{2}$. 


\section{B}
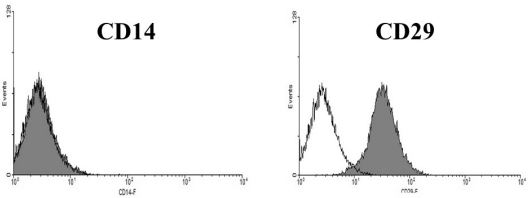

A
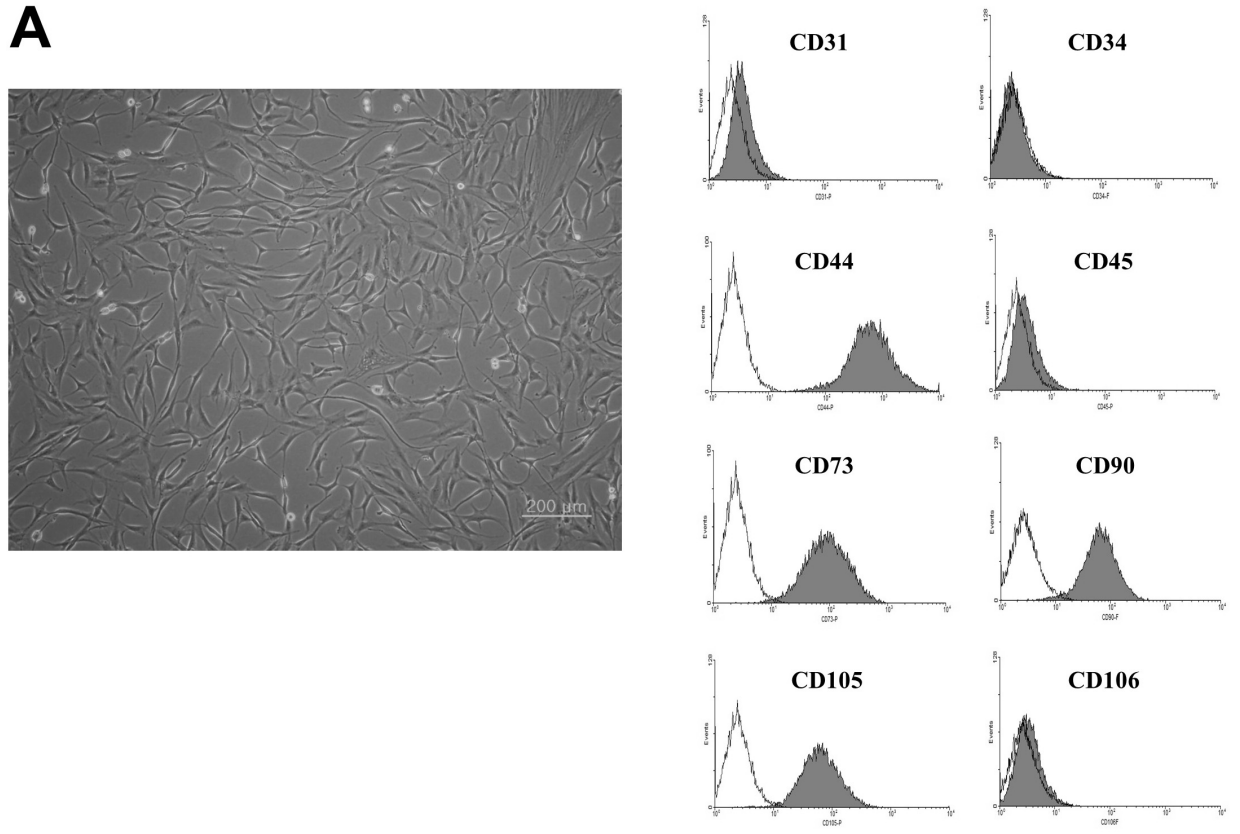

CD106

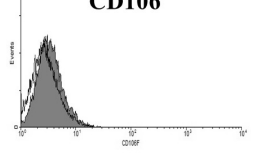

Fig. 2. Mesenchymal stem cells isolated from bone marrow. Figure shows the typical morphology of spindle-shaped mesenchymal stem cells (A, x100). Immunophenotype of isolated mesenchymal stem cells using flow cytometry (B).

A

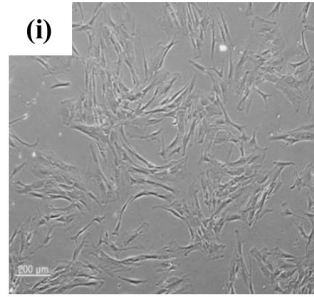

(ii)

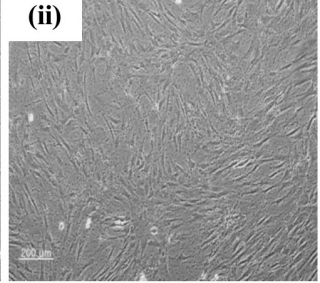

B
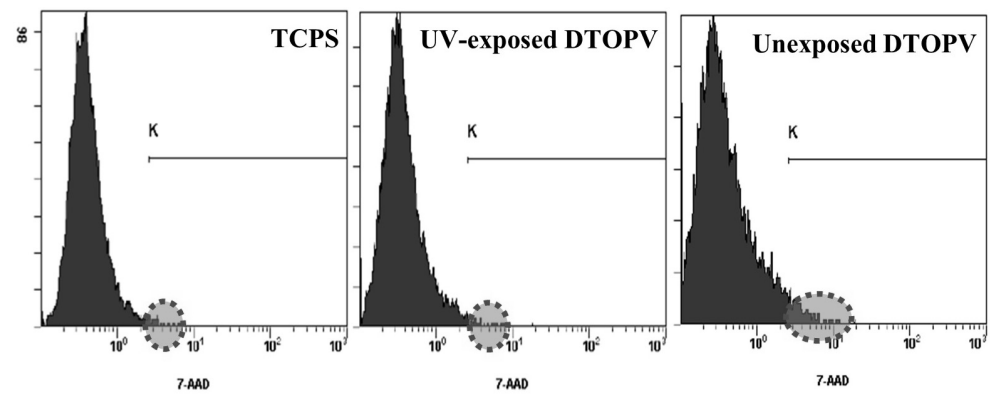

(iii)

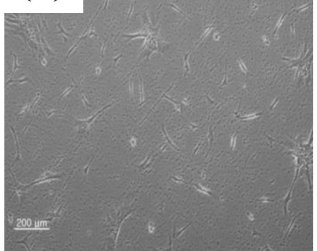

7.AAD

Unexposed DTOPV

6.4

Fig. 3. Optical microscopic image of MSCs cultured on (i) TCPS as a reference, (ii) UV-exposed DTOPV film (DTOPV+UV), and (iii) unexposed DTOPV film (DTOPV-UV) in culture medium containing serum for six days (A, x100). Analysis of biocompatibility from a cell apoptosis experiment quantified using 7-AAD (B). 


\section{Chondrogenic differentiation using UV-exposed DTOPV film}

Methods have been developed to create suitable environments that will enhance the chondrogenic differentiation efficiency of MSCs (Djouad F et al., 2006). It is crucial to provide three-dimensional culture environments while maintaining stability for the chondrogenesis of MSCs. It was hypothesized here that the UV-exposed DTOPV polymer provided a good microenvironment for differentiation.

The water contact angle of unexposed DTOPV was 97.11 ${ }^{\circ}$, and that of UV-exposed DTOPV was $83.14^{\circ}$ (Fig. 4A). As depicted in Fig. 1, the formation of carboxyl groups, via photo-oxidation of DTOPV during UV exposure, resulted in generating a hydrophilic surface. MSCs selectively attach onto hydrophilic surfaces (Mitchell SA et al., 2005). It was found that MSCs grown on UV-exposed DTOPV for four days changed into a globular form observed in pre-cartilage condensations (Fig. 4B). Safranine O staining showed that differentiated cells on UV-exposed DTOPV were strongly stained compared with those on TCPS (Fig. 4B). In addition, the expression of Type II collagen gene was upregulated in cells on DTOPV compared to that of TCPS (Fig. 4C).

\section{Discussion}

MSCs derived from the mesoderm can readily differentiate into osteocytes, adipocytes, and chondrocytes under the proper environmental conditions. Despite this capacity, MSCs cultured in monolayers exhibit limited chondrogenesis. Thus, various induction methods have been developed, including culture using pellets and biocompatible polymers for efficient chondrogenic differentiation of MSCs (Djouad F et al., 2006). To overcome the limitations, a novel technique

\section{A}

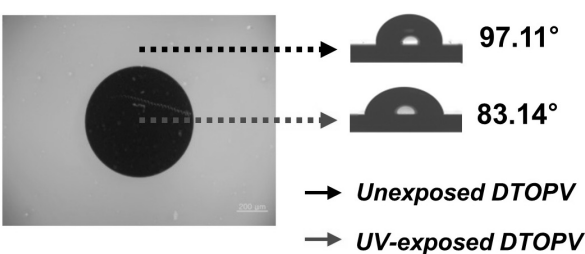

B

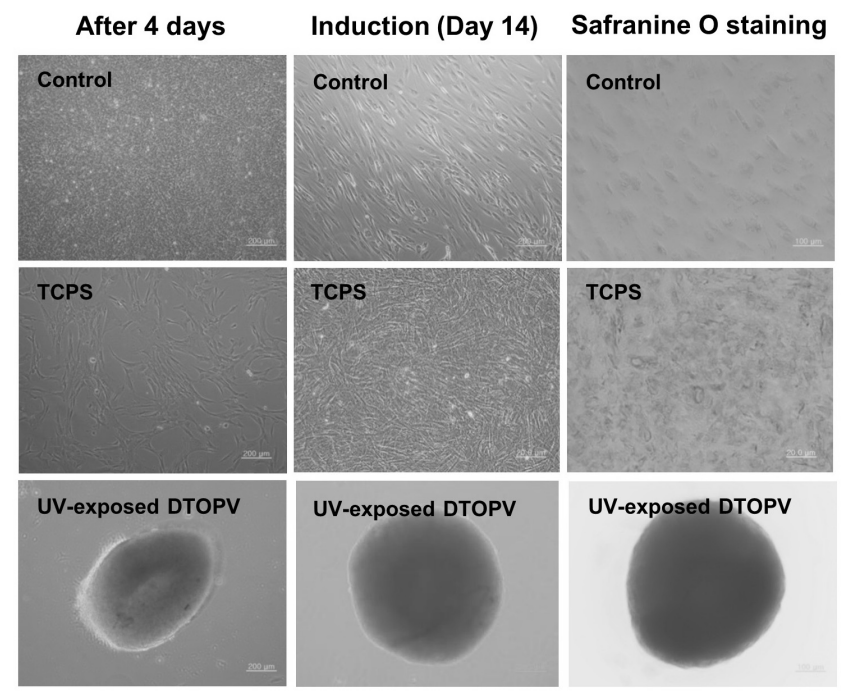

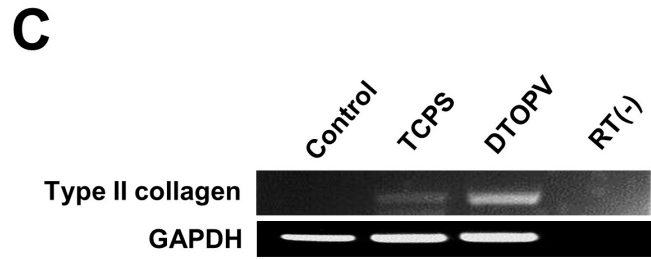

GAPDH

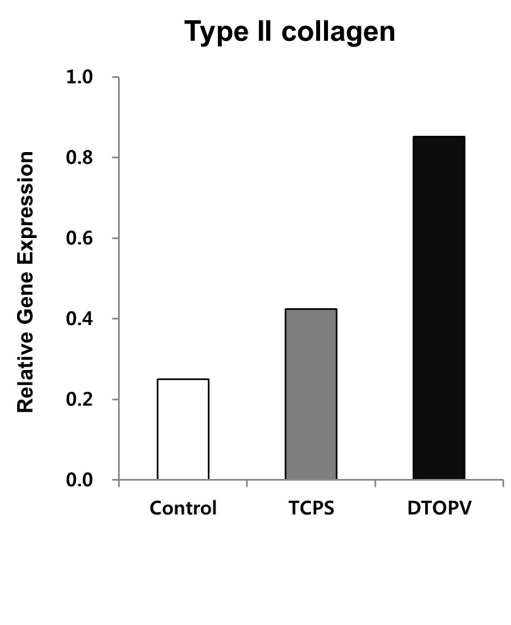

Fig. 4. Change in contact angle depending on UV irradiation time. UV-exposed region is more hydrophilic than unexposed region (A, fluorescent images, $\times 100$ ). Chondrogenesis of MSCs using patterned DTOPV and assessment of chondrogenesis by Safranine O staining (B, optical images, x100) The expression level of Type // collagen gene was analyzed by RT-PCR. The signal intensity of the product was normalized to its respective GAPDH signal intensity (C). 
was developed based on the biocompatible polymer used throughout this study.

Recent studies have demonstrated that the surface of a polymer is of great importance in controlling cell fate and function (Jiao YP \& Cui FZ, 2007). Although the interactions between cells and polymer surfaces have been extensively studied, the complex process underlying these interactions is not fully understood. Nonetheless, it is evident that presence of functional groups on the surface of a polymer can influence cell-to-cell and cell-to-substrate interactions. It was previously shown that UV-exposed DTOPV enhanced the proliferation and adherence of MSCs (You J et al., 2009). In the present study, a polymer-coated substrate was applied to create a favorable environment for chondrogenesis and to improve the rate of differentiation. Results showed remarkably high chondrogenic differentiation on the polymer-coated substrate compared with that on conventional TCPS.
MSCs reside in a specialized in vivo niche consisting of an extracellular matrix (ECM), which is composed of fibronectin and collagen. The ECM provides structural and biochemical support to cells and regulates functions such as cell adhesion and differentiation (Michel G et al., 2010). Previous results have shown that the surface of UV-exposed DTOPV retained more ECM proteins than TCPS did, resulting in enhanced cell adhesion and proliferation (Kim H-S et al., 2010). These properties of the polymer might provide a suitable microenvironment to increase the efficiency of MSC chondrogenesis. Furthermore, we can confirm from the data that a polymer-patterned surface can be utilized as a biomaterial in numerous biomedical fields.

Biomaterials research in diagnostics and drug studies has recently become an important issue in the biomedical field (Stevens MM \& George JH, 2005). Therefore, MSCs were differentiated into chondrocytes on micropatterned polymers

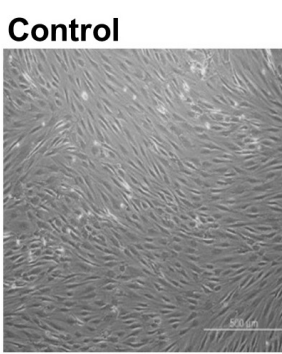

Day 4

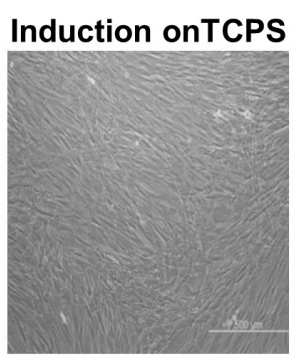

Day 4

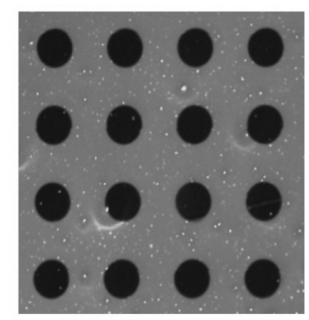

Induction on 150um dot-patterned DTOPV

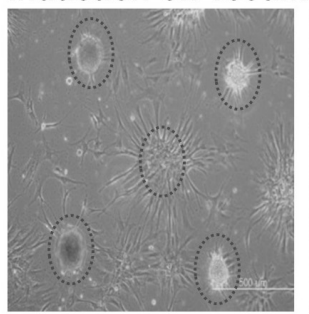

Day 4

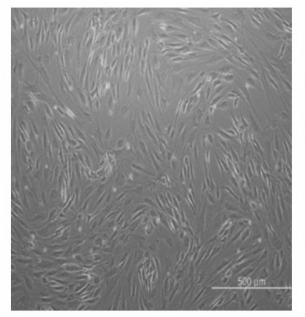

Day 7

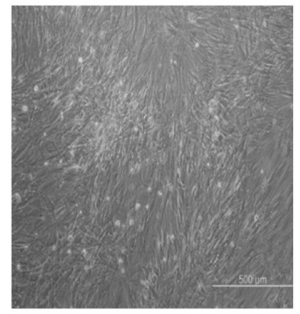

Day 7

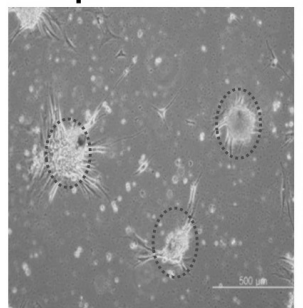

Day 7

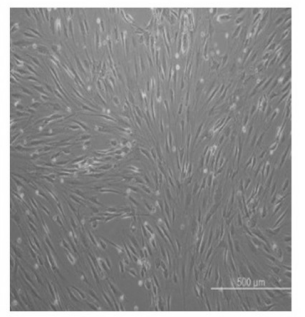

Day 14

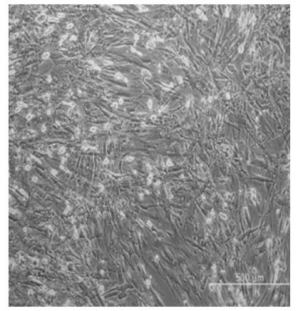

Day 14

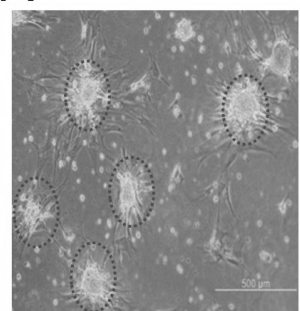

Day 14

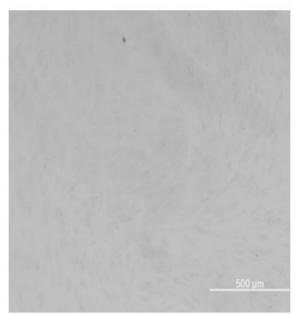

Safranine 0

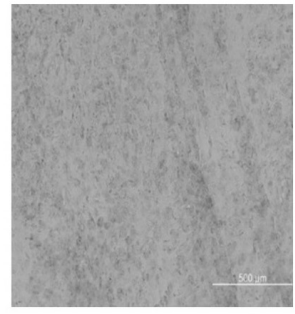

Safranine 0

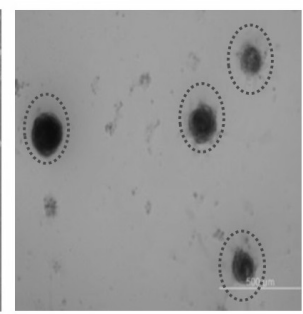

Safranine 0

Fig. 5. Fluorescent images of DTOPV substrate and chondrogenic induction of MSCs on TCPS and micropatterned DTOPV substrates (x100). 
to investigate the effects of the mechanical features of microstructured surfaces and its availability in biomedical applications such as in drug screening. Fig. 5 shows that a dot-micropattern with a diameter of $150 \mu \mathrm{m}$ was formed through UV exposure. MSCs selectively attached to the patterned DTOPV, which was exposed to a UV source, and were induced into chondrocytes (Fig. 5). In addition, the cells on the patterned polymer were strongly differentiated into chondrocytes compared with those on TCPS, as shown in Fig. 5. These results indicated that the polymer has the potential to be used as a biomaterial in the fields of bioengineering, diagnostics, and gene and drug studies.

In conclusion, the properties of interfaces between materials and cells represent the key to successful bioengineering applications. The MSCs cultured on UV-exposed DTOPV showed a higher proliferation rate than that on traditional TCPS substrate. The cells cultured on UV-exposed DTOPV were more strongly stained with Safranine O compared with those on TCPS, and chondrogenic differentiation of MSCs proceeded more rapidly on the polymer than on TCPS. Also, Type II collagen gene was strongly expressed in cells induced on UV-exposed DTOPV. These results demonstrated that UV-exposed DTOPV is a highly efficient substrate for the chondrogenesis of MSCs. The biopolymer could be used as a material for effective chondrogenic differentiation of MSCs in cartilage tissue engineering. Finally, these biocompatible polymers can also be used for in vitro diagnostic purposes, such as drug screening and array chips.

\section{요 약}

중간엽줄기세포는 손상된 관절연골 치유능력을 가지고 있어 줄 기세포 치료 분야에서 대표적인 성체줄기세포로 알려져 있다. 자외 선이 조사된 생체 친화성 필름 조성물인 DTOPV (S-triazine bridged p-phenylenevinylene)는 친수성 특성의 표면을 가진 형 광 화합물이다. 이전의연구에서 물질표면의 습윤성과 친수성이 세 포부착 및 증식에 중요한 역할을 하는 것이 확인 되었으며, 이번 연 구에서는 DTOPV를 이용하여 중간엽줄기세포의 연골분화능을 향 상시키고자 하였다. 일반 배양용기로 사용하고 있는 TCPS (tissue culture polystyrene)와 자외선이 조사된 패턴된 DTOPV 필름을
이 실험에 사용하였고 TGF (transforming growth factor)- $\beta 3$ 가 포함된연골분화배지로 중간엽줄기세포를 2주동안 분화유도를 하 였다. TCPS에서 배양된 중간엽줄기세포는 단층으로 자라면서 분 화가 유도된 반면, 자외선이 조사된 DTOPV 필름 위에서 배양된 세 포는덩어리진 구형으로 형태가 변하였으며, 연골세포에 특이적으 로 염색되는 Safranine O 염색으로 DTOPV 조건에서 더 붉게 염색 됨을 관찰하였다. 또한 연골세포 특이적인 유전자인 Type II collage이 DTOPV 조건에서 더 강하게 발현되는 것을 확인함으로 써 TCPS보다 DTOPV에서 연골세포로 분화가 향상된 것을 알 수 있 었다. 따라서 자외선이 조사된 생체 친화성 필름 조성물인 DTOPV 을 이용한 경우에 일반 배양용기보다 빠르게 연골분화가 이루어짐 을 알 수 있었다. 결론적으로 향후 조직공학 분야에서 DTOPV가 중 간엽줄기세포의 효과적인 연골분화 물질로서 활용될 수 있는 가능 성을 확인 하였으며, 더 나아가 약물 스크리닝과 같은 진단분야에 활용될 수 있음을 알 수 있었다.

\section{Acknowledgements: None}

Funding: None

Conflict of interest: None

\section{References}

1. Caplan Al. The mesengenic process. Clin Plast Surg. 1994,21: 429-435.

2. Cho H, Kim E. Highly fluorescent and photochromic diarylethene oligomer bridged by $\mathrm{p}$-phenylenevinylene. Macromolecules. 2002,35:8684-8687.

3. Cho H-K. Isolation and characterization of cells from human adipose tissue developing into osteoblast and adipocyte. Korean J Clin Lab Sci. 2008,40:106-112.

4. Djouad F, Mrugala D, Noel D, Jorgensen C. Engineered mesenchymal stem cells for cartilage repair. Regen Med. 2006,1: 529-537.

5. Friedenstein AJ, Piatetzky-shapiro II, Petrakova KV. Osteogenesis in transplants of bone marrow cells. J Embryol Exp Morphol. 1966,16:381-390.

6. Jiang Y, Jahagirdar BN, Reinhardt RL, Schwartz RE, Keene CD, Ortiz-Gonzalez XR, et al. Pluripotency of mesenchymal stem cells derived from adult marrow. Nature. 2002,418:41-49.

7. Jiao YP, Cui FZ. Surface modification of polyester biomaterials for tissue engineering. Biomed Mater. 2007,2:R24-37.

8. Kim H-S, Heo JS, You J, Park T, Choi Y, Kim E, et al. Fast and efficient isolation of mouse bone marrow-derived mesenchymal stem cells by using a biocompatible polymer. Tissue engineering and regenerative medicine. 2010,4:443-451.

9. Michel G, Tonon T, Scornet D, Cock JM, Kloareg B. The cell wall polysaccharide metabolism of the brown alga Ectocarpus siliculosus. Insights into the evolution of extracellular matrix 
polysaccharides in Eukaryotes. New Phytol. 2010,188:82-97.

10. Mitchell SA, Davidson MR, Bradley RH. Improved cellular adhesion to acetone plasma modified polystyrene surfaces. J Colloid Interface Sci. 2005,1:122-129.

11. Shin H, Jo S, Mikos AG. Biomimetic materials for tissue engineering. Biomaterials. 2003,24:4353-4364.

12. Stevens MM, George JH. Exploring and engineering the cell surface interface. Science. 2005,310:1135-1138.

13. Wang W, Itaka K, Ohba S, Nishiyama N, Chung UI, Yamasaki Y, et al. 3D spheroid culture system on micropatterned substrates for improved differentiation efficiency of multipotent mesenchymal stem cells. Biomaterials. 2009,30:2705-2715.

14. Yoo J, Kwon T, Sarwade BD, Kim Y, Kim E. Multistate fluo- rescence switching of s-triazine-bridged $\mathrm{p}$-phenylene vinylene polymers. Appl Phys Lett. 2007,91: 241107-1-241107-3.

15. You J, Heo JS, Lee J, Kim H-S, Kim HO, Kim E. A fluorescent polymer for patterning of mesenchymal stem cells. Macromolecules. 2009,42:3326-3332.

16. You J, Raghunathan VK, Son KJ, Patel D, Hague A, Murphy CJ, et al. Impact of nanotopography, heparin hydrogel microstructures, and encapsulated fibroblasts on phenotype of primary hepatocytes. ACS Appl Mater Interfaces. 2015, 17;7(23):1229912308.

17. You J, Shin DS, Patel D, Gao Y, Revzin A. Multilayered heparin hydrogel microwells for cultivation of primary hepatocytes. Adv Healthc Mater. 2014,3:126-132. 